\title{
THE LABOUR PARTY AND EDUCATION FOR SOCIALISM
}

No socialist since Robert Owen has had any excuse for being unaware of the relationship between educational reform and social and political change, and a perception of this relationship was a feature of nineteenth century socialism and liberalism. The attention which the educational principles and policies of socialist, labour, and radical movements in Europe have recently received has thus been well deserved. ${ }^{1}$ The socialists have however come off better than those organisations which have been designated as merely "labour", and two valuable contributions to the literature dealing with Great Britain - Professor Simon's Education and the Labour Movement, 1870-1920, and Dr Reid's article on the Socialist Sunday Schools - are concerned with the programmes and beliefs of left wing socialist bodies, rather than with those of the ideologically more diffuse but politically more important Labour Party. Both these contributions may perhaps profitably be placed in a new perspective by an examination of the attitudes adopted within the Labour Party and within its industrial half-brother the Trades Union Congress, to the problems raised by the content and character, as opposed to the structure and organisation, of the education available to the working class.

This education took two principal forms. On the one hand was the official educational system, comprising the publicly maintained and the voluntary schools, the various teacher training and further education colleges, and the universities. On the other were the various supplementary, voluntary systems, such as the Workers' Educational Association, the Adult Schools, and the Plebs League, which sought

1 E.g., J. E. S. Hayward, "Educational Pressure Groups and the Indoctrination of the Radical Ideology of Solidarism, 1895-1914", in: International Review of Social History, Vol. VIII, Part 1 (1963). Brian Simon, Education and the Labour Movement, 1870-1920 (London, 1965). Harold Silver, The Concept of Popular Education (London, 1965). D. R. Watson, "The Politics of Educational Reform in France during the Third Republic, 1900-1940", in: Past and Present, No 34 (July 1966). F. Reid, "Socialist Sunday Schools in Great Britain, 18921939”, in: International Review of Social History, Vol. XI, Part 1 (1966). 
to give men and women, in their own time, the opportunities which they had not been given by the official system. A similar task was performed by the residential college, such as Ruskin College, Oxford, which was associated with the official system and received government grants whilst drawing support and funds from organisations such as the trade unions; and the Central Labour College, London, which depended entirely on voluntary support from students and trade unions and other non-official resources. These different forms were all subsumed under the general heading of "education" within the Labour Party, because despite their variety they all provided the same precious commodity of which it was felt the working class had been deprived.

Opinion in the Labour Party with regard to the content of education was frequently illustrated not so much by being positively asserted as by being implied by the rejection or neglect of the tradition described by Dr Reid. This tradition is perhaps most strikingly represented by the Plebs League, founded in October 1908 by discontented students of Ruskin College, Oxford. Ruskin College, while aiming to serve the working class by educating trade unionists and thus rendering them more effective both industrially and politically, believed that this should be done via a conventional course of impartial but critical social studies. The Plebs League denied the possibility of impartiality, especially in social and political studies, and argued that the conventional tradition in this field, and hence at Ruskin too, was necessarily slanted against the interests of working class and socialist reformers. In 1909 the League, with support from some trade unions, set up the Central Labour College as a "declaration of Working Class Indepen-

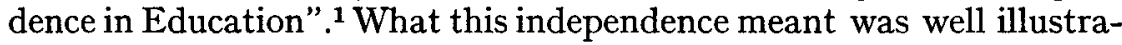
ted by the sub-warden of the new College who told the Adult Education Committee of the Ministry of Reconstruction that:

"The Labour College teaches the workmen to look for the causes of social evils and the problems arising therefrom in the material foundation of society; that these causes are in the last analysis economic; that their elimination involves in the first place economic changes of such a character as to lead to the eradication of capitalist economy."2

1 Plebs League, The Burning Question of Education (2nd edition, 1910), p. 22, quoted in: Brian Simon, Education and the Labour Movement, 1870-1920 (London, 1965), p. 324.

2 Ministry of Reconstruction, Adult Education Committee, Final Report, pp. 222-3, quoted in: Brian Simon, Education and the Labour Movement, 1870-1920 (London, 1965), p. 330. 
By the time that the College was founded the Plebs League was also responsible for a number of local adult classes, and in 1920 both residential and spare-time education were placed under the aegis of the National Council of Labour Colleges, which had on it representatives of the Central Labour College, the Plebs League, local classes, and supporting trade unions.

The Plebs League was informally associated with the Labour Party by an overlap of membership, especially via the trade unions. But looking at opinion on education within the Party in the first half of the twentieth century what is striking is the complete contrast with the tradition exemplified by the League and described by Dr Reid. In the first place the Labour Party, despite dissenting voices, never ceased to rely primarily on the official system for meeting the educational demands of the working class. In the second place it was not generally greatly interested in an issue which was central to the tradition represented by the Socialist Sunday Schools: a concern with the content of education. ${ }^{1}$ It was not commonly believed within the Party that the actual material of the curriculum was the main cause of whatever social and political effects education might have. In so far as interest was expressed in the effects of the content of education, it was largely centred on the official system and normally lacked a political colour. The Party shared in this respect a common position

1 There was some discussion of teaching methods within the Party, but this had no distinctive labour or socialist character. For instance the examination which the Party's Advisory Committee on Education made of the Dalton Plan and of other teaching methods between 1923 and 1925 was carried out by educationalists who were also Labour supporters or sympathisers, but it had no features which would have distinguished it from a discussion of similar topics by Conservatives or Liberals. There has always been in fact a great deal of educational policy, as of other policy, which lies completely outside the scope of political aims and party differences and which cannot usefully be understood in terms of them.

The source for information about the Labour Party's Advisory Committee on Education, and the subsequent Education Advisory Committee, is the collection of unpublished minutes, memoranda, and correspondence in the possession of the Labour Party at Transport House. I am indebted to the General Secretary of the Party for having given me permission to use these. I have designated them "Transport House Papers", and have hereafter abbreviated this to "THP". The reference for the above footnote is thus: THP Advisory Committee on Education memoranda: 99, 1923; 116a, 1924; 117a, 1925; 129, 1925.

The comment of the otherwise undistinguished delegate of the Willesden Labour Party to the 1945 Party Conference is illuminating though untypical: "We in the Labour Movement have, I think, in the past failed in one very important aspect of education. We have been inclined to demand the shilling against the Tory sixpence, the extra year against the Tory extra six months. But we have omitted to get down to the real question of educational methods." E. Leigh-Davis, Labour Party Annual Conference Report (1945), p. 127. 
with other major British political parties and reflected a widespread belief that it was not the business of a central ministry, nor the concern of national policy, to determine the method, manner, or matter of instruction within the schools. As the former school teacher, Alice Bacon, speaking for the Party's National Executive, told the 1945 Labour Conference, "I hope that ... we shall leave the teachers to experiment as much as they can and not lay down just what should be taught." 1 This neglect of curricula may be taken as an indication of the extent to which the ethos of the existing educational system was accepted. The chief desire which emerged in the Party's approach to education was not for the destruction of an old order, nor for the massive utilisation of unofficial, voluntary agencies to counter the effects of the teaching within that order, but for the broader dissemination of a tradition which, by and large, was accepted, admired and envied. The aim was fairer shares not a new society. The language which was always familiar within the Party often gave the impression that a new heaven and earth were in the making. But in the field of education there was a tacit assumption that all would be well if only the advantages of the old heaven and the old earth were spread more evenly. ${ }^{2}$

This optimism was the inheritance rather than the creation of the Labour Party. For a tradition can be identified, common to both liberalism and socialism in the nineteenth century, of a hopeful expectancy towards the effects of the spread of public education - a hope that as a result of the increasing provision of a freely accessible, national system, the level of intelligent citizenship and of articulate and democratic political self-assertion would be raised. William Morris considered that "socialism is advancing, and will advance more and more as education spreads", and Joseph Chamberlain had made free primary education one of the principal items of his radical programme of $1884-5 .^{3}$

By 1900 this tradition had been little modified. Thirty years after the Education Act of 1870 had laid the foundations for a national system of elementary education, and 25 years after the franchise had

1 Labour Party Annual Conference Report (1945), p. 128.

${ }^{2}$ Cf. Brian Abel-Smith, Labour's Social Plans, Fabian Tract 369 (London, 1966), p. 18: "In many respects socialism is about levelling up. This is precisely what our aim should be in health, education and social security. We want to give everyone the costly education the wealthy have long enjoyed, to give everyone the amenities that go with BUPA medical care, to give everyone the standard of social security provided under the best occupational schemes."

${ }^{3}$ J. W. MacKail, Life of William Morris, vol. 2 (1912 ed.), pp. 109 ff., quoted in: M. Beer, History of British Socialism (3rd edition, London, 1940), pp. 250-1. Peter Fraser, Joseph Chamberlain (London, 1966), p. 45. 
been extended to a majority of the adult male population, a reliance on the mere fact of education, irrespective of its content, might have seemed no longer enough. Parliament remained the preserve of aristocratic and middle class parties, to whom the working class elector regularly doffed his vote. But the Labour Party, which began life as the Labour Representation Committee in 1900, still regarded a conventional education within the official system as the glittering prize for the working class child. A repudiation of the traditions of the English schools would have been inconceivable, and in these circumstances the only avenue of criticism open was one which recommended the strengthening of elements already supposed to be present in the schools. The positive citizenship which it was hoped would emerge from a developed system of public education was not forthcoming, but the solution still lay in education. "Democracy", wrote Ramsay MacDonald in 1900, "can be made efficient only by the education of the individual citizen in civic virtues." 1 In much the same spirit twelve years later the Labour Party Conference of 1912 called for:

"a generous measure of educational reform in the direction of providing facilities for liberal, as distinct from technical, education, thus laying the basis of the national life in an educated democracy".

The school curriculum should be modified, thought the conference,

"in order that in the later year of school life more time may be given to instruction in the duties of citizenship."2

Nevertheless, as significant as the comment of MacDonald or the resolution of the 1912 Conference were the remarks of the resolution's mover, J. M. McTavish, who was later to become secretary of the Workers' Educational Association. A recommendation for the stressing of citizenship education was, he said, the one major omission from the educational programmes of the left wing Gasworkers' and General Labourers' Union which the Party Conference had endorsed on

1 J. R. MacDonald, "The People in Power", in: Stanton Coit (editor), Ethical Democracy (London, 1900), p. 73. "The faith that the voice of the people is the voice of God is now about thirty years out of date", argued MacDonald. "Those who held it assumed that an enfranchised democracy would be wide awake to every political issue ... The experience of thirty years goes to show that the democracy took infinitely more interest in getting the vote than they have taken in using it." Ibid., p. 60.

${ }^{2}$ Labour Party Annual Conference Report (1912), p. 104. 
numerous previous occasions. ${ }^{1}$ He had struck on a significant omission. For even the mild and sympathetic criticism of the existing educational system implied by the request for more citizenship training was not reciprocated in the Party as a whole. Despite the occasional suggestions made before the First World War and sporadically at other times, the general acceptance throughout the Party's history of the existing character of the school curriculum meant that even the belief in the role of education in promoting citizenship played no significant part in the educational programmes of the Labour Party. One contemporary commentator in 1925, a year after the collapse of the first Labour Government, was led to express his surprise at the lack of thought that had been put into formulating schemes of education for a socialist commonwealth. ${ }^{2}$

There was a remarkable continuity in opinion on this matter. And it was an opinion which, although sometimes taken to imply some additions to the school curriculum, assumed that progress lay through the promotion of unity rather than of conflict in society. It was one of the major themes of the Party's principle educationalist in the inter-war years, R. H. Tawney, that education could provide a common meeting place for children of diverse social origins and hence a common basis for an integrated social life. ${ }^{3}$ It is not therefore surprising to find

1 Labour Party Annual Conference Report (1912), pp. 104-5.

2 Lewis Rockow, Contemporary Political Thought in England (London, 1925), pp. 123-4. Of the plans of the Webbs and MacDonald, Rockow commented: "Yet fully to achieve this goal as regards the masses it is incumbent, we submit, to institute an appropriate scheme of political education. This subject, however, our authors barely touch upon. It is commonplace to note that more important than the reformation of political institutions is an improvement in the intelligence of the mass of the electors. It is less commonplace to develop a plan of civic education. Yet if democracy continues to be merely, as Shaw mentioned, a substitution for the corrupt few of the incompetent many, the situation is discouraging. If Bobus insists upon electing Bobissimus, political reforms will little avail. Collectivism, especially, depends upon an active civic enlightenment ... Without such consciousness any construction of a political edifice must inevitably be as futile an effort as painting lilies... There should be, however, a book on education in the socialist state parallel with the constitution of the Webbs." ${ }^{3}$ E.g., R. H. Tawney, Secondary Education for All (The Labour Party, London, 1922). Cf. Chuter Ede, who was to be Labour Parliamentary Secretary at the Board of Education in the 1940-5 coalition: "a constitutional democracy has to face up to problems that in the past were relegated to a very few people in this country. If we are to have a democracy capable of shouldering this great burden, I am quite sure that it can only be done through giving to the children of all classes of the community a greater opportunity of entering into those great heritages of literature, of art and of beauty that should enrich the lives of the community." Official reports of Parliamentary Debates are cited in the official manner. The reference for Chuter Ede's speech is thus: 229 HC Deb., 5 s., c. 365 ; 4th July 1929. 
very similar sentiments being expressed during the same period outside the Labour Party. In 1926 the Conservative Leader, Stanley Baldwin, told an audience at Stirling:

"We live in a democratic age, in a democratic country, and unless the democracy [sic!] are educated in the true sense and the real meaning of the word no amount of vision amongst the few, however enlightened, can save the people from perishing."1

The opinion of Ralph Morley, the Labour MP for Southampton, that the end of education should be the creation of,

"a nation of men and women with sufficiently wide culture to fit them to be the ruling citizens in a State which has for its basis a democratic constitution". ${ }^{2}$

was scarcely distinguishable from that of Lord Irwin who, as President of the Board of Education in MacDonald's second National Government, declared that the first requirement in contemporary education:

"was good citizens. The democratic state depended ultimately on the average judgment of its average member, and it was, or ought to be, one of the main objects of education not to conduct mass propaganda, but to win for its clients the gift of right judgment in all things, the power to discuss truth, and the power to distinguish in public affairs the genuine coin from the spurious." 3

Thus in recommending an education to prepare men and women for citizenship, the Labour Party was expressing a widely held sentiment, which received approbation from, for example, the Report of the Board of Education's Consultative Committee in 1939.4 Nor was this sentiment restricted to the years before 1939. It was strengthened as a result of the outbreak of the Second World War when the vision of

1 Glasgow Herald, 27th January 1926; quoted in the National Union of Conservative and Unionist Associations publication, Gleanings and Memoranda, Vol.

LXIII (London, January-June 1926), p. 267.

2255 HC Deb., 5 s., c. 868; 16th July 1931.

3 The Times, 6th January 1933.

4 Board of Education, Report of the Consultative Committee on Secondary Education (Spens Report) (London, 1939), pp. xxxvii and xxxviii. Cf. "TUC Memorandum to the Consultative Committee, 19th July 1934", in: Trades Union Congress Report (1934), p. 145. Barbara Drake, State Education, New Fabian Research Bureau Research Pamphlet 35 (London, 1937), pp. 21-2. 
the Nazi State creating its youth in its own image led observers in Britain to hope that in their own country education might give,

"every boy and girl such a belief in the institutions of his country that he will not only be willing to die but - a much more difficult thing - to live for this country too". ${ }^{1}$

The optimism of peace was as effectual in this respect as wartime patriotism; and when the Labour Party came to discuss the county colleges which it was hoped would follow the Education Act of 1944, they were attributed a prominent role in citizenship education. ${ }^{2}$

Thus with remarkable consistency the Party held to its liberal inheritance. It did so with a largely unspoken belief which was most strongly asserted only when challenged. Two features emerge from a study of these challenges. The occasions on which they were mounted and on which they gained some support or credence within the party can be identified as providing an environment for temporary radicalism, when educational policies were not necessarily the only ones to feel the pressure of militancy. But more striking is the ineffectiveness of these challenges, and it is in an examination of them and more especially of their failure to achieve any lasting impact, that the character of the Labour Party's position emerges most clearly. The main interest of the occasions when the Party seemed to toy with an ideological critique of the curriculum lies in the way in which the real nature of party opinion was illuminated by being reasserted, and by the defeat or demise of the militant position.

\section{MILITARISM IN EDUCATION}

It was the experience of war, right at the start of the Labour Party's life, which had led some to dissent from the almost unqualified, optimistic acceptance of the developing work of the schools. It also led to doubts amongst some socialists as to whether the educational experience of the nation's children might not contain harmful elements.

1 Robert Richards, Labour MP, 380 HC Deb., 5 s., c. 1429; 16th June, 1942. Cf. Harold Clay, Labour Party Annual Conference Report (1942), p. 141: "We have seen in another country how the educational system has been used for the destruction of all that we value in this Movement, and we have got to use our educational system not less effectively and not less resolutely."

2 Labour Party Annual Conference Report (1946), pp. 192-5. 
The anti-militarist tradition of the ILP, most notably represented by Keir Hardie, had been roused by the Boer War, whilst the "Khaki" election of 1900 had seemed to show that the popular sentiments aroused by such a war might be exploited for party political ends. ${ }^{l}$ Even before the election, when in March 1900 the Commons discussed the motion of a Conservative member to introduce compulsory physical and military training into the schools in order to improve moral and bodily fitness, John Burns, linking socialism and liberalism, protested that the mover's real object was:

"not gymnastics, but militarism". "If the army wants recruits you have two great recruiting sergeants - one is poverty, which procures you 95 per cent., and the other is patriotism, which gets you 5 per cent. What is now being proposed, it seems to me, is to increase by fictitious and adventitious aids, by military drill in the playground, that 95 per cent. The working classes do not want these, and, what is more, they won't have it."2

The anti-war feeling of socialists and of members of the Labour Party in the House of Commons showed itself in a sensitivity to anything in the schools which might encourage a militaristic attitude amongst the children. In 1906 Keir Hardie complained that:

"the churches and the schools were being used as recruiting agencies for popularising the Army and familiarising the youth of the country with military ideas and drill."3

Philip Snowden and Summerbell expressed similar opinions; ${ }^{4}$ in April

1 Emrys Hughes, Keir Hardie (London, 1956), pp. 94-9. Asked in January 1900 by the New York Times, "What is the chief danger, social or political, which confronts the new century?" Hardie replied, "Militarism!", ibid., p. 109. R. C. K. Ensor, England, 1870-1914 (Oxford, 1936), p. 267.

281 HC Deb., 4 s., c. 844 ; 30th March 1900. Cf. also 119 HC Deb., 4 s., c. 1303-4, $1310-11 ; 19$ th March 1903 . The concern for the health of the nation was associated with a concern for its imperial greatness and Gilbert has observed that "Many imperialists sought in addition to use improvement of the English physique as an argument for the establishment of military training." Bentley Gilbert. The Evolution of National Insurance in Great Britain (London, 1966), p. 94. The Earl of Ronaldshay had attempted, against the opposition of Barnes, to amend the Education (Scotland) Bill of 1908, so as to institute military drill in the schools: 196 HC Deb., 4 s., c. 194-206; 10th November 1908.

3152 HC Deb., 4 s., c. 194; 19th February 1906. Cf. also 163 HC Deb., 4 s., c. 425-7; 25th October 1906.

4 Snowden: 163 HC Deb., 4 s., c. 704-5; 29th October 1906. Summerbell: 173 HC Deb., 4 s., c. $702 ; 30$ th April 1907. 
1906 the annual conference of the ILP resolved that it "strongly reprobates every attempt to inculcate military training in schools"; 1 and in 1907 the Labour Party Conference passed a resolution condemning:

"the manifold efforts now being made to popularise (militarism) by the proposals for citizen armies, and to poison the minds of youth by means of School Rifle Clubs, Boys' Church Brigades, and the like". ${ }^{2}$

The War of 1914-18, so different in scale and impact from the Boer War, was the occasion for a series of formal commitments in the Party to banish militaristic influences from the schools. Although the Labour Party had given its support to the government and had been a member of the coalition from May 1915, it had very briefly opposed the war up until the invasion of Belgium on 4th August 1914, and even thereafter, when under Arthur Henderson the Parliamentary Labour Party supported the war both in the Commons and on the recruiting platform, there remained a significant rump, especially amongst members of the ILP and numbering among its more prominent members MacDonald and Snowden, which retained its hostility to the war and to the policy of the government. Even amongst those who supported the official party line there was a good deal of uneasiness, quelled partly perhaps by the belief that such support was a short term, tactical measure rather than a permanent surrender of principle. In May 1917 the mood of one broad section of opinion associated with the Labour Party was shown when a conference was called by the Workers' Educational Association to discuss educational reconstruction after the war. The conference was attended by representatives of the Trades Union Congress Parliamentary Committee, the Labour Party, a number of unions and trade councils, and local Labour Parties, Workers' Educational Associations, and co-operative organisations, ${ }^{3}$ and it passed an amendment put forward by the Poplar Trades Council and Labour Representation Committee recommending the exclusion of any form of military or military-style training from the curricula of the continuation schools proposed in the government's Education Bill. ${ }^{4}$

The following year, 1918, the Labour Party's January Conference rejected the composite resolution on education laid before it and sub-

1 Independent Labour Party Annual Conference Report (London, 1906), p. 42.

${ }^{2}$ Labour Party Annual Conference Report (1907), p. 62.

- Workers' Educational Association, Report of National Conference on Educational Reconstruction (London, 1917), pp. 56-74.

4 Ibid., p. 35. 
stituted one which included the demand that physical training should not be based on military methods. ${ }^{1}$ In May, J. H. Whitehouse, a Liberal, moved an amendment to the Education Bill to exclude "military training" from the continuation schools which children were to attend on a part-time basis after the age of $14 .^{2}$ His amendment was resisted by Fisher, the Liberal President of the Board of Education, whilst five Labour members of the Coalition Government - Barnes, Clynes, Hodge, Parker, and Roberts - voted against it. They were supported by three other Labour MPs including Alexander Wilkie and Ben Tillett. Thirteen ${ }^{3}$ Labour MPs supported Whitehouse (including MacDonald, Bowerman, Jowett, J. H. Thomas, Snowden and F. W. Goldstone of the National Union of Teachers, and amongst the 31 others voting for the amendment were two Liberals later to join the Labour Party: Buxton and Ponsonby. ${ }^{4}$ A month later, the Executive Committee of the Party reported to the June Conference that the Parliamentary Party had "made itself responsible" for an amendment to prevent physical training in schools having a military bias. ${ }^{5}$ This was a misleading claim, and when in July Whitehouse again sought to amend the Bill, the Labour vote was once more divided, six voting for the amendment - joined this time by another future recruit to the Labour Party, the Liberal H. B. Lees-Smith, briefly to be President of the Board of Education in 1931 - and four Labour members of the coalition opposing. ${ }^{6}$ The Party Conference of 1919 passed a resolution similar to that of 1918; Mary Carlin, a national officer of the Dockers' Union, comparing military training to "the very system which made Germany what it was". " In 1921 the Party Executive in a memorandum submitted to the Board of Education and prepared by the Advisory Committee on Education, stated that physical training in schools should be of a non-military character and that there should be no military training in state aided schools. ${ }^{8}$ In 1922, J. W. Bowen of the Post Office Workers told the TUC that he wanted children "to be taught not so much the glories of war as the blessings of peace!"9

After 1919 however little more was heard of this theme within the

1 Labour Party Annual Conference Report (January-February 1918), p. 135.

2105 HC Deb., 5 s., c. 2182; 8th May 1918.

3 One Labour MP also acted as teller, making 14 in all.

4105 HC Deb., 5 s., c. 2182-2220; 8th May 1918.

5 Labour Party Annual Conference Report (June 1918), p. 22.

- 108 HC Deb., 5 s., c. 749-58; 15th July 1918.

7 Labour Party Annual Conference Report (1919), pp. 164-5.

${ }^{8}$ Labour Party, Local Education Schemes; Memo submitted to the Board of Education by the Executive Committee of the Labour Party (London, July 1921), p. 3.

- Trades Union Congress Report (1922), p. 413. 
Party. It had been a response to the war and did not long outlive it. But anti-war sentiments continued to affect educational policies in some sections, especially at a local level. In 1929 the Bradford Independent Labour Party published a comprehensive report on education, in which it commented:

"The social implications of an Officers' Training Corps are twofold. It is playing at soldiers, that most fascinating of games, and for all it is worth, adolescent nature being what it is, direct propaganda for war. The cant of national defence deceives no one."1

In 1930 the Annual Conference of the Independent Labour Party called on the new Labour President of the Board of Education, C. P. Trevelyan, to carry out a survey of teaching methods "with a view to the removal from curricula of all historical teaching based on out-of-date text books and on a nationalistic and imperialist outlook". ${ }^{2}$ In 1935, the year in which at a national level the Party rejected pacifism by driving Lansbury from the leadership, the London County Council, of which Labour had won control for the first time the previous year, refused to authorise school cadet corps, ${ }^{3}$ and the new Council renamed Empire Day, Commonwealth Day, ${ }^{4}$

"the council treats the training of the coming generation as a sacred trust, and not an opportunity for disguising the beastliness of war as a pageant or a game. Labour refuses to spend rate-payers' money for 'Hitlerising' the schools", 5

as the Party put it, in a judicious appeal to both the consciences and the pockets of local electors. Other Labour controlled councils - in Wales, the north-west, and the north-east - took steps at this time to discourage school cadet corps, and refused to allow teachers time off for territorial army work, or to permit school trips to military tattoos. ${ }^{6}$

The outbreak of war in 1939 destroyed much of the force of this style of pacifism in the Party as it had not done in 1914, though even in 1942, W. G. Cove, Labour MP and an active and prominent member

1 Report of Commission on Education appointed by Bradford Independent Labour Party, Vol. 3 (Bradford, 1929), p. 22.

2 Independent Labour Party Annual Conference Report (1930), p. 108.

3 Labour Party, What Labour Has Done for London (London, 1936), p. 7.

- H. Morrison, An Autobiography (London, 1960), pp. 148-9.

5 Labour Party, What Labour Has Done for London (1936), p. 7.

- Conservative Party, Politics in Review (London), Vol. 3, No 2 (April-June 1936), pp. 126-7; and Vol. 3, No 3 (June-September, 1936), pp. 73-4. 
of both the National Union of Teachers and the National Association of Labour Teachers, was able to protest at posters advertising military training for boys between the ages of 14 and 16:

"My hon. Friends on these benches want to win the war, but I hope they do not want to do so at the expense of the militarisation of youth."1

Just before the end of the war, in April 1945, the Labour controlled Monmouth County Council decided to ban cadet corps from its schools, and in the same month the conference of the Co-operative Party called for the discontinuance of all junior service organisations. ${ }^{2}$ Some of this sentiment survived in the Parliamentary Labour Party in the 1960s: when in 1964 the Conservative Sir Charles Taylor recommended the development of cadet corps in schools, all the Labour members who took part in the ensuing debate expressed a preference for less formal kinds of youth training, such as the Boy Scouts. ${ }^{3}$ But antimilitarist feelings never again reached the intensity which they had achieved before 1918. And even before 1918 their expression was not the prelude to any effective educational programme.

THE PROBLEM OF POLITICAL BIAS

The traditional Labour position was also assailed by critics who argued that the teaching provided in the schools was politically biased. This view gained currency between the two world wars, at a time when the Party, whilst established as a significant parliamentary force for the first time, was unable effectively to capture control of government. A feeling of frustration both with the Party and with the restraints which it was felt that the existing order placed on its activities, provided an environment in which doubts as to the neutrality of the school curriculum were able to gain some confidence.

Criticisms of political bias in the school curriculum began to be voiced within the Labour Party at a time when the attacks on militarism were declining into insignificance. The apparent success of Lloyd George in translating the propaganda and enthusiasm of war into an

1380 HC Deb., 5 s., c. 1469; 6th June 1942.

2 Daily Express, April 10th and 3rd 1945, quoted in the Conservative Central Office publication, Notes on Current Politics, VI (London, 1945), pp. 13-4.

8694 HC Deb., 5 s., c. 777-874; 1st May 1964. 
instrument for electoral victory in 1918, had an effect in the Labour Party similar, though in a lesser degree, to that of the experience of war itself. In 1917 peace and reconstruction had been viewed with much uncritical optimism. ${ }^{1}$ But though the Representation of the People Act of 1918 had placed an extra 13 million men and women on the electoral register, there were only 57 Labour members in the new Parliament. MacDonald, Snowden, and Henderson all failed to gain a seat in the December election following the armistice. The Party's popular vote had increased, but so had the electorate, and those who had been expected to be the natural supporters of the Labour Party had, it appeared, failed in some way. Philip Snowden had little faith left in the good sense of the people and observed bitterly:

"The bringing of a considerable number of working men into political power has certainly not realized the expectations of the working class leaders who expected much greater things than have been achieved from the enfranchisement of the people. Government by an autocracy is a danger and a tyranny. But the nominal government of an ignorant democracy may be a greater danger to the State than even the despotism of an autocracy... The painful exhibitions of lack of political principle, which we have seen during the last few years, the ease with which the populace can be swayed by a plausible politician, the influence over public opinion which is wielded by an unprincipled Press, the indifference of a large percentage of the electorate to the exercise of the franchise, the selection and election of persons with no qualifications to fill important positions in local administration and in Parliament, are evidences of the need for a better and truer education, an education which will teach the citizens to use their power wisely and well."2

Just as the opponents of militarism had proposed a reformation of values and practices in the schools, so a similar response was made by

1 E.g., Arthur Henderson, The Aims of Labour (London, 1918) (the pamphlet was written the previous year), p. 19: "There never was a bigger opportunity for democracy to achieve its main aims than the one which now offers."

${ }^{2}$ Philip Snowden, Labour and the New World (London, 1921), p. 224. Cf. A. J. Cook, Trades Union Congress Report (1922), p. 303: "you can waste thousands of pounds in the financing of an election, but you must educate your people before the election." The TUC General Council subcommittee on education observed, in its Report and Recommendations to the 1922 Congress: "The development of the working-class movement has not yet arrived at a stage when the majority of the organised workers and their wives can be relied upon to vote Labour from conviction." Trades Union Congress Report (1922), p. 189. 
those who discerned deficiencies in the political awareness of the populace. Snowden suggested that the people suffered from too little education, but he had also recommended that what they had be improved. In this respect he approached the position adopted by the Plebs League with regard to voluntary, adult education. The League, via the trade unions, was able to gain some publicity for its views within the labour movement in the early post war years. The times were auspicious for it: the Labour Party was suffering from a feeling of political frustration yet was the possessor of a more clearly articulated socialist policy, promulgated in the programme and constitution of 1918. The trade unions were entering a period of militancy, with the miners and railwaymen taking the lead. The National Union of Railwaymen and the South Wales Miners Federation were co-owners of the Labour College, and C. T. Cramp, the railwaymen's president and a personal supporter of the National Council of Labour Colleges, discussed a resolution before the 1918 Trades Union Congress in the following terms: ${ }^{1}$

"We not only deal with the machinery for the administration of the educational system, but we deal also with the curriculum in the elementary and secondary schools, especially as regards the teaching of history and the kindred subjects, 'so that in training the children of the working class in the ideals of citizenship they may have presented to them a clear view of the real life and development of the population of this and other countries.' In the past too little attention has been given to that kind of education, because we have been too fond of considering the machinery. We have to realise that the point of view, which is such an important thing for us in the Labour movement in later years, as possessed by the great mass of citizens, is acquired in the elementary school, when the mind of the child is most receptive. We want our point of view, therefore, emphasised inside the elementary schools.

When compulsory education was introduced into this country it was said by a certain statesman, 'You will be educating your masters.' That gentleman was unduly apprehensive. He did not know that the people in the schools could so teach the children that they would believe that the domination of the community by one particular class was a just and natural thing, and that

1 Cramp signed a manifesto of the National Council of Labour Colleges in 1925, together with Smillie, Cook, Purcell, Ellen Wilkinson, and others. Daily Herald, 26th February 1925, quoted in Gleanings and Memoranda, Vol. LXI (London, January-June 1925), p. 452. 
kind of teaching has continued, and unfortunately our class has believed it."'1

Cramp expressed a similar opinion at the second Labour Party Conference of that year, when he said that he regretted the absence of any clause demanding the teaching of citizenship. ${ }^{2}$ But neither at the Trades Union Congress nor at the Party Conference were his views echoed or even challenged by other speakers. Indeed at the Trades Union Congress he complained:

"I am sorry there is such a thin Congress, because it is only when the workers take over the education system themselves that they will realise that the children must be properly trained."3

But this was not an uncommon complaint by those discussing education, either at the conferences or in Parliament. One or two speakers at congresses and conferences over the next five years referred to the matter of bias in the curriculum, and it was suggested that employers should not be allowed control over any of the part-time continuation schools provided for by the Education Act of 1918 because they would use the schools "in order to perpetuate the present condition of society". ${ }^{4}$ But though the circumstances for a sustained effort to commit the Party in this area existed between 1918 and 1923 they were not exploited with any consistency. ${ }^{5}$

The school curriculum did not in fact become a subject of great interest or debate within the Labour Party until after the formation in 1923 of the Teachers' Labour League (TLL). But the League, in addition to being an educational pressure group, became associated with the attempts of the Communist Party of Great Britain to infiltrate the Labour Party via the latter's constituent organisations, following the rejection in 1920 and 1921 of applications for formal Communist affiliation. In 1927 the TLL was disaffiliated from the

1 Trades Union Congress Report (1918), p. 305.

- Labour Party Annual Conference Report (1918) (June), p. 72.

3 Trades Union Congress Report (1918), p. 305.

4 S. P. Viant of the Amalgamated Carpenters and Joiners in: Trades Union Congress Report (1919), p. 350.

5 The TUC of 1918 passed a motion calling for "revision of the curriculum now obtaining in the elementary and secondary schools, especially in the teaching of history and allied subjects". The Labour Party Conference of 1923 passed a resolution calling for the elimination of "the false historical instruction and military training by which Capitalism, Militarism, and Imperialism seek to poison the mind and injure the body of childhood". But on both occasions there was an excess of acquiescence over enthusiasm and both resolutions were carried without debate. Trades Union Congress Report (1918), p. 303. Labour Party Annual Conference Report (1923), p. 237. 
Labour Party, as were several other organisations, and its impact on educational policy came to an abrupt end. But during its brief period of association it was able to claim some success in raising the issue of school curricula to a new, if transitory, prominence.

The Teachers' Labour League was formed after a conference in May 1923 which had been called to discuss the formation of a Teachers' Labour Group, and it held its second meeting in the following January. ${ }^{1}$ From the beginning it was under strong pressure from its left wing and communist members, and in December 1924 following the collapse of the first Labour Government, a Manchester delegate moved that the League was a socialist organisation which should affiliate internationally. His amendment was defeated by 312 votes to 140 , but the following December the League's 1925 Conference agreed, by 291 votes to 211, to affiliate to the communist controlled Education Workers' International. ${ }^{2}$ By that date communists had gained control of a number of constituency Labour Parties, and the vote at the TLL Conference represented a further victory for the policy of infiltration. ${ }^{3}$ The League's President, H. S. Redgrove, put forward a policy which came close to applying the ideas of the Plebs League to the schools, and called for the replacement of anti-socialist bias with a more sympathetic and positively favourable treatment:

"citizenship ... should come first in the list of school subjects. The child should understand his rights and privileges and what the community expected from him. This meant that he must understand the principles of Socialism."4

In 1926 at the TLL's fifth conference, hostility between the Labour and Communist factions came to a head. A secret session passed a resolution demanding class conscious education in the schools, and after a battle for the control of the executive committee, the anti-communist minority, which included the general secretary C. P. Bell, the treasurer A. B. Coleman, and the parliamentary secretary Morgan Jones (who had been a junior minister at the Board of Education in the 1924 Labour Government), seceded to form their own rival committee. ${ }^{5}$

1 The Times, 21st May 1923 and 5th January 1924. Labour Press Service, 10th April 1924.

2 The Times, 31st December 1924. The Times, 30th December 1925.

${ }^{3}$ Henry Pelling, A Short History of the Labour Party (London, 1961), pp. 53-4.

4 The Times, 30th December 1925.

5 Daily Herald, 31st December 1926, quoted in: Gleanings and Memoranda, Vol. LXV (London, January-June 1927), pp. 227-8. The Times, 30th and 31st December 1926. Asher Tropp, The School Teachers (London, 1957), p. 216, footnote 17. 
By the time of the split however, the League had had some formal success in putting across its policies within the Party. Its first attempt to place the authority of a Labour Conference behind its policies was made in the autumn of 1925, a few months before the decision to affiliate to the Education Workers' International. The report on education which the Party's Executive Committee presented to the Conference mentioned the conciliatory Labour resolution on secondary education which had been accepted by the Commons in April 1925. ${ }^{1}$ This drew criticism from the delegate of the Tamworth Labour Party, C. R. King, who made it clear that he was speaking on behalf of the Teachers' Labour League. He questioned whether a policy agreed to by all parties could be acceptable to the Labour Party, and moved the reference back of that section of the report which dealt with education because, he said, it was concerned with the structure rather than with the content of education:

"It was not sufficient for the Labour Party to aim at the extension of Education of the existing type - more scholarships, more places at the University, free maintenance, etc. That was all right, but it did not go far enough. What they wanted was a revolution in the present type of Education ... the aim of which was largely to provide efficient wage-slaves for the capitalist system. The aim of an Educational Policy, he claimed, should be to bring about a better type of Education tending towards the establishment of the Socialist Co-operative Commonwealth. The only way in which they could get a better state of things was to have a better people."2

But his motion was lost, and the Bristol delegate who seconded it complained not of the character of the curriculum, but of what she considered an inadequate commitment to the principle of free secondary education. ${ }^{3}$ The conference later passed a composite resolution which drew on both the original Executive resolution and the addendum originating from the TLL. But the latter, which had rejected "the mere extension of facilities for education of the existing type", and called for "definite training of children for the citizenship of the Cooperative Commonwealth to be"4 was diluted so as to do no more than call for:

${ }^{1}$ Labour Party Annual Conference Report (1925), p. 102. 182 HC Deb., 5 s., c. 2350; 8th April 1925.

${ }^{2}$ Labour Party Annual Conference Report (1925), p. 214.

3 Labour Party Annual Conference Report (1925), p. 215.

4 Labour Party Annual Conference Agenda (1925), pp. 12 \& 15. 
"the development of types and methods of Education which will create amongst children the qualities and outlook essential to citizens of a Co-operative Commonwealth."1

The following year the policies of the TLL met with better success. The President of the League, H. S. Redgrove, moved a resolution which was carried by the Party Conference and which stated that the Conference condemned:

"the widespread reactionary and imperialistic teaching in the schools, particularly with regard to Empire Day celebrations and the use of history and other text books with an anti-working class bias; and therefore calls upon the Educational organisations of the Labour Movement, Labour School Managers, and Labour Members of Education Authorities to take steps to prevent the further celebration of Empire Day, and to investigate the school books in use with a view to eliminating those written from an anti-working class point of view."2

The proposal to purge the schools of hostility to the "working class point of view" could have been understood to have been no more than an unfortunately phrased advocacy of impartiality, though the injunction to Local Education Authorities and school managers might have alarmed some. But there was no such ambiguity about a resolution submitted by the Manchester Borough Labour Party and the Liverpool Trades Council and Labour Party. ${ }^{3}$ This called for the establishment of a "Workers' Committee of Inquiry" one of whose duties would be:

"To determine the part Education must play in abolishing the present and creating a new Order of Society", and "To prepare a report as to how far the present books, pictures and other materials used in schools, and the predominant methods of teaching and disciplining children, foster a bourgeois psychology, militarism and imperialism; and as to how far, under a workers' administra-

1 Labour Party Annual Conference Report (1925), p. 293.

${ }^{2}$ Labour Party Annual Conference Report (1926), pp. 265-6.

${ }^{3}$ Labour Party Annual Conference Agenda (1926). The Teachers' Labour League seems to have had a number of Manchester members amongst its leading left wingers, but I have been unable to discover the extent, if any, of TLL influence over the Manchester and Liverpool resolution. It echoes the speech which Redgrove himself made the previous year at the League's own conference, and is the first appearance at a party conference of such an extreme demand. 
tion, this might be counteracted and a proletarian attitude towards an outlook on life might be cultivated."1

An attempt was made to move the previous question but this was defeated, and the resolution carried by $2,583,000$ votes to $160,000 .{ }^{2}$ But it was unusual for educational resolutions to be sufficiently controversial to lead to any vote at all. The resolution, and its passing, was a shift to the left by the Conference, though the delegates were not prepared to go so far as to accept another motion pledging support for the National Council of Labour Colleges. ${ }^{3}$

In 1926, resolutions passed at a conference which was otherwise cautious, dispirited, and hostile to militancy following the failure of the General Strike, ${ }^{4}$ were not well received by the party leadership. Not only was the party conducting a defensive action against the Communist Party to their left, but to their right the Conservatives were making full use of the bogey of red revolution as the coal strike dragged on. ${ }^{5}$ The Conservatives were generally hostile to trade unionism at this time, particularly where it seemed to them to be a carrier into the public services of left wing political involvement. The 1927 Trade Disputes and Trade Union Act had given expression to this position, and in the same year Conservative teachers groups were formed:

"To combat the teaching of Socialism and Communism in schools, and frustrate generally the activities of the 'Teachers' Labour League"'. 6

Lord Eustace Percy, Conservative President of the Board of Education, warned the North of England Education Conference against:

1 Labour Party Annual Conference Report (1926), p. 264.

${ }^{2}$ Labour Party Annual Conference Report (1926), pp. 264-5.

Ibid., p. 265.

- Beatrice Webb, Diaries, 1924-32, edited by Margaret Cole (London, 1956), pp. 120-1.

5 Gleanings and Memoranda, Vol. LXIV (July-December 1926), p. 351; Vol. LXV (January-June 1927), pp. 148-9; Vol. LXVI (July-December 1927), pp. 65-6 \& 480. The former Labour education Ministers, Morgan Jones and C. P. Trevelyan, did their best to deflate the accusations of Government spokesmen in this matter: 202 HC Deb., 5 s., c. 1944-5; 24th February 1927. 204 HC Deb., 5 s., c. 702-4 \& 708-9; 24th March 1927.

${ }^{6}$ Gleanings and Memoranda, Vol. LXV (January-June 1927), p. 408. A London Conservative Teachers' Association was formed, and included a similar policy amongst its objects: Gleanings and Memoranda, Vol. LXV (January-June 1927), p. 543. 
"a constant and conscious effort among a large section of our fellow-countrymen to conduct political propaganda, directly or indirectly, among our children". ${ }^{1}$

Even the Workers' Educational Association came under Conservative attack in the Commons the following year, from a backbencher who accused it of being a channel of socialist propaganda. ${ }^{2}$ The mixing of education and politics in this fashion during and after the General Strike led to unfortunate incidents. In Durham a head teacher had his certificate withdrawn by the Board of Education after he had interfered in the provision of school meals for the children of miners who were not on strike. The local Conservative Party appears to have had a hand in the affair and the matter was taken up by both Labour and Conservative Parties at a national level as a minor political scandal. ${ }^{3}$ The Labour Party had no wish to appear as the advocate of an attack on those very traditions of educational impartiality to which it itself adhered. The Teachers' Labour League had been captured in December 1926 by a group whose policies differed sharply from those of the Party but whose activities were being used by the Conservatives to discredit Labour. And allegations were made by Labour critics of the TLL that, following the consolidation of Communist control in 1926, the League had organised campaigns against Party spokesmen on education in the latter's own constituencies. In 1927 the League was disaffiliated, together with 23 Constituency Labour Parties which

1 The Times, 7 th January 1927, quoted in: Gleanings and Memoranda, Vol. LXV (January-June 1927), p. 225. But the Conservative position on school curricula was not always so different from the attitude which they criticised. In January 1927 Eustace Percy, as President of the Board of Education, told a deputation from the Royal Society of St. George that "It ought to be perfectly clearly laid down by the Board of Education, by local authorities, by the teaching profession, by everybody who is connected with education, that patriotism is the very foundation of our teaching in the school." Daily Telegraph, 28th January 1927, quoted in: Gleanings and Memoranda, Vol. LXV (January-June 1927), p. 371.

2215 HC Deb., 5 s., c. 1777-8; 3rd April 1928. 216 HC Deb., 5 s., c. 1054-5; 26th April 1928. Percy treated the suggestion with some ridicule, pointing out that he himself had written in the WEA's magazine, "The Highway", at which particular offence had been taken by the backbencher.

${ }^{3} 199$ HC Deb., 5 s., c. 1937-8; 18th November 1926. 202 HC Deb., 5 s., c. 1086-7 \& 1257-68; 17th February 1927. 204 HC Deb., 5 s., c. 659-69, 674-5, \& 702-5; 24th March 1927. 217 HC Deb., 5 s., c. 1138-9; 16th May 1928. The Labour Party's Advisory Committee on Education urged the National Executive Committee to "give the greatest possible publicity" to the cancellation of the head's certificate. THP Advisory Committee on Education minutes, 4th April 1927. 
had passed under Communist control, and a loyal National Association of Labour Teachers was formed. ${ }^{1}$

But the Executive of the Party was still left with an instruction from the 1926 Conference to report on a number of issues set out in the resolution on education. Among these issues was that of the curriculum and its reform. The Executive therefore announced that the Party's Advisory Committee on Education could be considered "a competent Workers' Committee" as demanded by the resolution, and the Committee's secretary, Beatrice Webb's niece Barbara Drake, drafted a report to answer the points raised. ${ }^{2}$ The Advisory Committee, which had first been formed as part of the Party's reorganisation of 1918, was predominantly a body of educationalists. Its most active members tended to be those who were professionally associated with either the official or the voluntary system. And in the Committee's early years a number of men and women who had little or no connection with the Labour Party as such were drawn to the Committee because they saw in it an opportunity to advance the cause of educational reform. The Committee's members were thus often educationalists who were also associated with the Labour Party, rather than socialists who were working out the educational implications of their ideology. ${ }^{3}$ It was thus perhaps not surprising that Barbara Drake's rebuff of the demand for the cultivation of "a proletarian attitude" was forthright:

"while we cannot ton strongly condemn any tendency on the part of local education authorities, or of school managers, to foster in the schools a militarist, or narrowly national or imperialist outlook, we should regard as equally reactionary and contrary to the best traditions of public education in this country an attempt to impose on immature young minds a particular labour or socialist creed or any brand of class conscious psychology ... It is, in our opinion, not the function of the school to play a direct

1 Labour Party Annual Conference Report (1927), pp. 173-6. Henry Pelling, A Short History of the Labour Party (London, 1961), p. 54. Daily Herald, 9th March 1927, quoted in: Gleanings and Memoranda, Vol. LXV (January-June 1927), p. 527.

${ }^{2}$ Labour Party Annual Conference Report (1927), pp. 52-3. THP Advisory Committee on Education minutes, 14th March 1927.

3 Beatrice Webb, Diaries, 1912-24, edited by Margaret Cole (London, 1956), pp. 116-7. M. A. Hamilton, Arthur Henderson (London, 1938), pp. 225-6. THP Advisory Committee on Education minutes. Tawney himself was of course a notable exception to the non-ideological nature of many committee members' interest in education in so far as he related his views and proposals on a whole range of topics to his firmly held social and political ethics. 
part in abolishing the present or creating a new order of society, but we rely on the strengthening of character and the growth of intelligence which are the fruits of true education to prepare the way for realisation of labour and socialist ideals." 1

This was too forthright it appears for the sub-committee which considered the draft and which included Tawney, Trevelyan, Cove and Mrs. Drake herself. ${ }^{2}$ They prepared a new draft which omitted the condemnation of an education designed to inculcate "a particular labour or socialist creed", and whilst commending a broad and critical education, expressed the belief that such an education "must be the necessary foundation of a Labour and Socialist Commonwealth". ${ }^{3}$

At the 1927 Conference at which the Advisory Committee's Report was presented, the true interest of the delegates in the condition of teaching in the schools was evident in the total lack of support for $\mathrm{H}$. $\mathrm{S}$. Redgrove, now attending as delegate for Croydon, in his opposition to the educational composite. He complained that it omitted references to the grievances listed in the "Margate Resolution" of 1926 and he raised again the accusation of bias against the working class movement in the schools and the slanted contents of textbooks. But the conference accepted the composite laid before it with no mention of bias in the curricula, just as the previous year it had supported one which, owing in part to the activity of a vigorous, and now proscribed, pressure group, had made bias one of its main points. ${ }^{4}$ At the Trades Union Congress of 1927 as well, an attempt to move the reference back of the General Council's Report because of the absence of any reference to the character of school history in the Council's evidence to the Government's Joint Committee on Education and Industry, was unsuccessful. ${ }^{5}$

After the expulsion of the Teachers' Labour League what little interest there had been within the Party in the ideological character of school curricula disappeared. The National Council of Labour Colleges which, with the TLL had been one of the major sources of "bias" propaganda in the 1920s, continued to denounce the effects of conventional education. ${ }^{6}$ But apart from a brief mention in the course of the long and thorough report on education by the Bradford ILP in

1 THP Advisory Committee on Education memorandum 165a, March 1927.

2 THP Advisory Committee on Education minutes, 4th April 1927.

3 THP Advisory Committee on Education memorandum 165b, May 1927.

4 Labour Party Annual Conference Report (1927), pp. 215-6.

5 Trades Union Congress Report (1927), pp. 333-5.

- E.g., Mark Starr, Lies and Hate in Education (London, 1929). J. P. M. Millar and Arthur Woodburn, Bias in the Schools (London, 1936). 
$1929,{ }^{1}$ the subject was not raised in the Labour Party or amongst associated organisations. There was an air of caution in the Party and amongst the unions after the failure of the General Strike and it was not until after the formation of the National Government of 1931 and the General Election of the same year that the matter was aired once more. ${ }^{2}$ After 1931 the party was frequently represented as being alienated from the political and social power structure and there was a marked swing to the left in the character of policy debates. ${ }^{3}$ Even so, the first attempt to draw the Party Conference's attention to the school curriculum in the 1930s was isolated and ineffective $\mathrm{s}^{4}$ and not until 1934 did H. L. Elvin, representing Cambridge University Labour Party, succeed in gaining the executive committee's acceptance in principle of an amendment to the draft policy statement, "Labour and Education". The amendment reflected the current campaign against war diplomacy in the Party and called for a pledge to:

"Eliminate from the curriculum of all State schools, of whatever grade, teaching calculated to encourage militarist or imperialist ideas, and secure an educational environment designed to train the new generation in international citizenship". 5

Though one supporter of the amendment was strongly influenced by Mark Starr of the National Council of Labour Colleges, ${ }^{6}$ the amendment itself carried none of the implications of those of 1925 and 1926. The fostering of international citizenship in the schools was a far less alarming doctrine than the preparation for a socialist commonwealth; it was in fact to be proposed by Tawney the following year. ${ }^{7}$ Even so, when the revised draft of the policy statement was published, Elvin's amendment was watered down, with its provocative references to

${ }^{1}$ Report of the Commission on Education appointed by the Bradford ILP., Vol. 3 (1929), pp. 21-2.

2 By the Labour MP for Mansfield, C. Brown: 270 HC Deb., 5 s., c. 1220-1; 16th November 1932.

3 Beatrice Webb referred to a "dour determination never again to undertake the government of the country as the caretaker of the existing order of society". Diaries 1924-32, ed. Margaret Cole (London, 1956), p. 292.

4 Councillor Dan Frankel in: Labour Party Annual Conference Report (1932), p. 251.

${ }^{6}$ Labour Party Annual Conference Report (1934), p. 216.

- Dr B. Lytton-Barnard, who quoted from "Lies and Hate in Education", in: Labour Party Annual Conference Report (1934), p. 218.

' Manchester Guardian, 17th August 1935, Leader. I am indebted to Lady Simon of Wythenshawe, and to Professor Brian Simon, through whom she made available to me a list of Tawney's contributions, both signed and anonymous, to the Manchester Guardian. 
"militarist or imperialist ideas" removed, and committed the Party to do no more than:

"secure an educational environment designed to train the new generation in citizenship in its widest and most generous aspects". ${ }^{1}$

Thereafter the idea virtually vanished from the Party, apart from an occasional reference to anti-socialist bias, ${ }^{2}$ and in 1938 the Party's Education Advisory Committee deferred any consideration of the teaching of civics, and of political bias amongst teachers and education authorities. $^{3}$ With the electoral victory of 1945 the Labour Party enjoyed its first period of majority rule. The concepts of the 1930s no longer had the same relevance, and it could hardly be maintained that the odds were stacked in such a way as to prevent a Labour government ever gaining effective power. When, in 1946, the educational resolution before the Party Conference called for the study of the trade union movement and of social history in the county colleges, it was as much an attempt to ensure a broad and balanced programme of relevant social studies as to create the ideology appropriate for a socialist society. ${ }^{4}$ Even so the executive found its recommendations too restricting and asked that the motion, which eventually was lost, be not pressed. ${ }^{5}$

But already in the 1930s there were signs of a different emphasis in references to the ideological role of education, the tone of which was illustrated by the delegate of Hemel Hempstead Labour Party in 1932 when he asked the Party Conference what steps were being taken to preserve the quality of civilisation by education for leisure. ${ }^{6}$ A similar concern for the aesthetically deadening effects of industrial production was shown by Chuter Ede in 1936, ${ }^{2}$ and the following year the Trades Union Congress, in its statement "Education and Democracy", com-

1 Labour Party, Labour and Education (London, December 1934), p. 1.

2 E.g., Neil Maclean: 329 HC Deb., 5 s., c. 1397-8; 25th November 1937. T. M. Sexton: 330 HC Deb., 5 s., c. 602; 9th December 1937. John Mack: 391 HC Deb., 5 s., c. 1985-8; 30th July 1943. Arthur Woodburn, Vice President of the National Council of Labour Colleges and Labour MP, Labour Party Annual Conference Report (1942), p. 143. In 1949 the matter was briefly reviewed by Peter Ibbotson in: Modern Education (the journal of the National Association of Labour Teachers), Vol. 3, No 2 (September 1949), pp. 29-30.

3 THP, LG 58 (February, 1938), p. 2. THP, Education Advisory Committee minutes, 7th February 1938, minutes 1; and 26th May 1938.

${ }^{4}$ Labour Party Annual Conference Report (1946), pp. 192-4.

5 Labour Party Annual Conference Report (1946), pp. 194-5.

6 Ben Greene: Labour Party Annual Conference Report (1932), p. 252.

7308 HC Deb., 5 s., c. 1232; 3rd February 1936. 
plained of the cultural deprivation suffered by the working class child. ${ }^{1}$ Philistinism and commercialism were to replace capitalism and imperialism as the leading bogeys whose influence it was thought the schools must combat, ${ }^{2}$ and in 1947 the Labour Minister of Education, George Tomlinson, told the Commons:

"If we want an alternative to the football pools, we should fill people's minds with something worth thinking about, and then perhaps they would not waste so much time thinking about pools. From the point of view of the development of further education, the life of the nation can, will and ought to be enriched, for I hold the view that just as the individual dies when he ceases to learn, so does the nation." 3

But here again no attempt was made to translate even this kind of interest in the curriculum into any programme of educational reform.

\section{III}

\section{INDEPENDENT WORKING CLASS EDUCATION}

Those who believed that the intellectual content of public education was inimical to the aims of the Labour Party or of socialism had two alternatives. If they believed that education played an important role in forming the political structure of society by directly imparting political beliefs and values, then they might (as did G. R. Mitchison in 1934 in his socialist utopia, The First Workers' Government ${ }^{4}$ ) propose a reform of the public system:

"such as to train citizens of a Socialist State and to provide as soon as possible those who could play their part towards the institution of such a State and in working its industry and services". 5

The other alternative was to provide an ideologically "correct" system of education in rivalry to the public system. This was a policy which

1 TUC, Education and Democracy (London, 1937), p. 16.

2 Horace King: 694 HC Deb., 5 s., c. 801-7, 1st May 1964.

s 441 HC Deb., 5 s., c. 662; 31st July 1947.

${ }^{4}$ G. R. Mitchison was a barrister and a member of the Executive Committee of the Socialist League at its formation in 1932. The First Workers' Government had an introduction by Cripps.

5 G. R. Mitchison, The First Workers' Government (London, 1934), p. 405. 
had been proposed since before the First World War by the Plebs League. The first issue of the League's magazine Plebs had called for "working-class education", ${ }^{1}$ by which was meant, not an education provided largely for manual workers, but an education based on a recognition of the "antagonism of interests existing between Capital and Labour". ${ }^{2}$ But though these two alternatives might spring from a single point of view they did not arise at the same time, nor did they always lead to fully related proposals. The policy of the National Council of Labour Colleges, for instance, was rather to repair the ideological work of the schools amongst the adult population, than to combat it at class-room level as the Teachers' Labour League wished to do, and in 1917 the Horrabins, members of the Plebs League, could write that:

"education in certain elementary subjects is wholly useful and desirable for everyone", ${ }^{3}$ and that "The State may be left to provide education in the elementary subjects." 4

Similarly a supporter of the National Council of Labour Colleges at the 1923 Trades Union Congress declared:

"It is only when we get out of the elementary and secondary schools and institutions that we come into the domain of education so far as the organised working class movement is concerned."5

As in the case of adult education generally, voluntary provision, even when based on revolutionary theory, was found where public provision did not yet exist or was not universal; the National Council of Labour Colleges described itself as a rival to the universities, never as one to the schools. It is interesting to note that the main attempt to do for children of school age what the National Council was attempting to do for adults - the Socialist Sunday Schools - had suffered from declining numbers since the beginning of the 1920 s. $^{6}$

1 W. W. Craik, The Central Labour College (London, 1964), p. 63.

2 J. F. H. \& W. H. Horrabin, What Does Education mean to the Workers? (Plebs League, London, 3rd edn, 1917), p. 7.

${ }^{3}$ J. F. H. \& W. H. Horrabin, What Does Education mean to the Workers? (Plebs League, London, 3rd edn, 1917), p. 3.

4 Ibid, p. 7.

- M. F. Titterington in: Trades Union Congress Report (1923), pp. 259-60.

- F. Reid, Socialist Sunday Schools in Britain, 1892-1939, in: International Review of Social History, Vol. XI, Part 1 (1966), pp. 40-41.

The only other similar venture was the Burston Strike school, founded in 1914, although the Kibbo Kift Kindred and the Woodcraft Folk carried out 
Neither the Plebs League nor the National Council of Labour Colleges of which it became a member, had any formal connection with the Labour Party, though the latter numbered several prominent Labour and trade union leaders amongst its supporters - the miners' leaders Robert Smillie, A. J. Cook and W. Lawther, the railwaymen's leader C. T. Cramp, the MP and trade unionist A. A. Purcell, who was President of the Trades Union Congress in 1924, and Ellen Wilkinson, who was to be Minister of Education in Attlee's first government. ${ }^{1}$ The National Council was, however, associated with a growing number of individual unions from 1923,2 and its views were frequently put forward at the Trades Union Congress in the 1920s. But the programme of independent working class education came close to what J. P. Nettl, describing the German Social Democrats, has called inheritor politics, ${ }^{3}$ and from before the First World War it had strong opponents in the trade unions. At the 1913 Congress, James Sexton, then a member of the Parliamentary Committee, complained that students of the Central Labour College were syndicalists and were attacking trade unionism. ${ }^{4}$ At this Congress, however, the supporters of the College fared better than they were to do in the 1920s. Congress referred back a motion by Bowerman, the secretary of the Parliamentary Committee, which called on trade unions to support Ruskin College, but which its critics, Gill of the Bolton Spinners and Hodges of the Miners, complained made no mention of the Labour College. ${ }^{5}$

During the militancy of the early 1920s, when the General Council

the same type of purpose in a less formally educational manner. For Strike Schools, see the Daily Mail, 25th February 1927, quoted in: Gleanings and Memoranda, Vol. LXV (January-June 1927), p. 526; and Independent Labour Party Annual Conference Report (1916), p. 93. For KKK and Woodcraft Folk, see W. H. G. Armytage, 400 years of English Education (London, 1964), Pp. 210-11. In October 1927 A. N. Branson, a member of the Executive of the ILP Guild of Youth, attacked the Scout movement, and suggested that a more class orientated movement might be formed. See the Sunday Worker, 23rd October 1927, quoted in: Gleanings and Memoranda, Vol. LXVI (July-December 1927), p. 480 .

1 See Manifesto in Daily Herald, 26th February 1925, quoted in: Gleanings and Memoranda, Vol. LXI (January-June 1925), p. 452.

2 National Council of Labour Colleges, Education for Emancipation (London, 1937), p. 7.

3 J. P. Nettl, "The German Social Democratic Party 1890-1914 as a Political Model", in: Past and Present, No 30 (April 1965), p. 67.

4 Trades Union Congress Report (1913), p. 335. Several of the early Ruskin students seem to have been sympathetic to syndicalism, and J. F. C. Harrison (Learning and Living, 1760-1960 (London, 1961), p. 294) says that a group of the Industrial Workers of the World was formed at the College. But Craik (The Central Labour College (London, 1964), pp. 83-4) denies this.

6 Trades Union Congress Report (1913), pp. 332-5. 
of the Trades Union Congress was considering the creation of a coordinated scheme of adult education, the supporters of the educational separatism proposed by the National Council of Labour Colleges argued vigorously for their views, but failed to carry either the Trades Union Congress or the Labour Party. In 1921 and 1926 when motions calling for support for the Labour Colleges and the National Council were brought before the Party Conference, the previous question was moved and carried, on one occasion after the intervention of Ramsay MacDonald. ${ }^{1}$ When at the 1922 Congress the familiar argument was reiterated that:

"just as it is necessary to have principles of our own, so is it necessary to have an education of our own",

it was roundly attacked by Jack Jones, an MP and a veteran of the General Workers. Jones's speech sums up well the orthodox trade union and Labour Party approach to the problems of education, both voluntary and public:

"the proposals which are being made in the speech of our friend who has just addressed Congress are reactionary propositions. Education is a national necessity, and it is our duty to see that we get the proper kind of education from national sources. Instead of that we are told we have to imitate the old sectarians, and have schools and colleges for each particular school of thought, circumscribed, so that we may educate people in particular theories ... some of us are not so much enamoured of the idea. What we ought to do is to capture some of the authorities who control education ... Can we, if we are going to adopt this policy of sectarianism, object to other people in their advocacy of sectarianism in educational matters? ... let us fight on the political field for the control of education, local and national, right from the elementary school to the university, and if the workers of the country will do their duty they will wake up and realise that the schools do not give the children the education they ought to have."3

When in 1924 George Hicks of the Building Trade Workers sought to amend the motion on trade union education in order to commit the scheme to embodying "the definite principles advocated by the Nation-

${ }^{1}$ Labour Party Annual Conference Report (1921), p. 212, and (1926), p. 265.

2 Trades Union Congress Report (1922), p. 287. Cf. Central Labour College statement, in: Trades Union Congress Report (1915), pp. 268-270.

3 Trades Union Congress Report (1922), p. 288. 
al Council of Labour Colleges and the London Labour College", he was persuaded by A. J. Cook to withdraw in the interest of unity. ${ }^{1}$ For it was Jones, and not the supporters of the Labour Colleges, who spoke for the central and fundamental tradition of British trade unionism in the twentieth century, epitomised by J. W. Bowen of the General Council when he told the 1923 Congress:

"It may be that the education to be given should lead up to control by the workers, but do not deny them at least the opportunities which the employing classes are securing for themselves!"2

There is little evidence of any desire in the Labour Party to miss these opportunities. The Conference of 1924 called for the government "to bring University education within the reach of all workers" both by an extension of opportunities within the universities themselves, and by public assistance to "independent working class education". ${ }^{3}$ But an amendment which declared that "Universities as present constituted are useless from the workers' point of view" 4 was not called, and at the Trades Union Congress of the same year, a delegate said:

"I understand, particularly from the resolution and speeches that have been moved and delivered at this Congress in years gone by, that we are out to get education free from the elementary school right up to the university. If we believe in that, why should we stultify ourselves by declaring that the universities of this country have nothing whatever to offer in the way of education for the working classes." 5

The general opinion within the Labour Party was quite out of tune with the formal purpose of the National Council of Labour Colleges to set up a rival system of higher education. ${ }^{6}$ At times, the National

1 Trades Union Congress Report (1924), pp. 423 and 427.

2 Trades Union Congress (1923), p. 260.

3 Labour Party Annual Conference Report (1924), pp. 167 and 169.

4 Labour Party Annual Conference Agenda (1924), p. 46.

5 J. Walker in: Trades Union Congress Report (1924), p. 423.

6 What the National Council of Labour Colleges formally described as its purpose, and the role it actually performed, were of course two very different things. It was the Workers' Educational Association not the National Council which provided adult education approaching a university standard, and although the Central Labour College provided full-time residential courses for adults, the work of the Council also spread through a whole range of studies down to grammar and composition. Moreover, much of the work of the National Council was not in rivalry to the work of the public system, but was supplementary to it. 
Council had gone so far as to suggest that the expansion of a publicly provided or assisted system of education would be positively harmful to working class interests. ${ }^{1}$ It made little impact between 1920 and 1926 when conditions were favourable for the reception of its proposals, and it is hardly surprising to find in 1943 the Trades Union Congress administering a polite but firm snub to the claims of the National Council to join the Council for Educational Advance, a body formed to campaign for the major educational reforms which were to be implemented by the 1944 Education Act:

"The National Council of Labour Colleges was left out because there was no evidence from the public pronouncements of that body that they were particularly interested in the general educational questions necessarily envisaged in a Education Bill."2

The basic premise of the case for independent working class education had been tacitly rejected by the Labour Party, both between 1918 and 1926 and after 1931. It followed that the actual proposals which stemmed from this premise scarcely had a foothold in the Labour Party and were firmly rejected by the Trades Union Congress.

Attacks on the school curriculum had been received more readily than had the advocacy of educational separatism, since the former often implied no more than disappointment with the public system of education, whilst the latter involved its rejection. The Party Conference of 1926 which accepted a motion of the Teachers' Labour League, defeated one calling for support for the National Council of Labour Colleges. But both the advocates of independent working class education and the critics of "bias" in the schools failed to make any but a brief and irregular impact on the Labour Party. On the occasions when they gained some support or assent for their views, when others expressed similar views, or when they succeeded so far as to cause discussion within the Party of their opinions, the Party itself was, or seemed to many of its supporters to be, in a particularly disadvantageous position. The militancy and disappointments of the eight years after 1918 and of the years following the formation of the national government of 1931 , occurred when it was easy to doubt the

1 E.g., cartoon by Horrabin in National Council of Labour Colleges, Education for Emancipation (1926), p. 5. A top hated gentleman is carrying, to the dismay of his colleagues, a bag marked: "Government Education Grants". "The Gang; But we thought the idea was an attack on the Unions. The Far-sighted Gent: Sh-h-h!! This is part of the game!"

2 G. W. Thomson, for the General Council, in: Trades Union Congress Report (1943), p. 180. 
fairness of the odds against Labour's chances of political success and when such doubt led to the proposition of radical policies and actions. Educational policies are thus in some measure a guide to the revolutionary or reformist character of the Party.

But the failure of the advocates both of educational separatism and of curricular reform to make any substantial and lasting impression on the Labour Party is of far greater significance than the formulation of radical policies by minority groups. The only political organisation which could reasonably claim to be the representative of the British working class remained stolidly committed to the values and ethos of the existing order in education. It sought to distribute the benefits of that order, not to change it. 